\title{
Early Performance of Two Apple Cultivars in Three Training Systems
}

\author{
David C. Ferree ${ }^{1}$ \\ Department of Horticulture, The Ohio State University, Ohio Agricultural \\ Research and Development Center, Wooster, OH 44691
}

\begin{abstract}
In 1987, 'Smoothee Golden Delicious' ('Smoothee') and 'Lawspur Rome Beauty' ('Lawspur') apple (Malus domestica Borkh,) trees were planted and trained as central leaders or palmette leaders on M.7 and Mark rootstocks or were planted as slender spindles on Mark rootstocks. 'Smoothee' trees were larger and had consistently greater yields and production per unit trunk cross-sectional area (TCA) than 'Lawspur' trees. Slender spindle trees had lower early yields per tree and TCA but had greater cumulative yields per hectare than trees in the other training systems. In the fifth and sixth growing seasons, 'Smoothee' trained as palmette leaders tended to have higher yields per hectare then central leader trees. Training system had little influence on 'Lawspur' tree yields. Limb bending in 1989 increased flower density in 1989 and 1990. Cumulative yield per hectare increased $11 \%$ as a result of limb bending of trees on Mark rootstock, but bending had no influence on trees on M.7 rootstock. 'Smoothee' on Mark had higher cumulative yields per hectare with the palmette leader and central leader than either 'Smoothee' on M.7 in either training system or any combination with 'Lawspur'.
\end{abstract}

The most proven method to increase apple orchard productivity and efficiency is intensive planting, using a precocious sizecontrolling rootstock, and applying the appropriate management system (Barritt, 1989; Ferree et al., 1989; Ferree and Rhodus, 1993; Robinson et al., 1991). Introducing Mark rootstock in 1981 (Carlson, 1981) offered the possibility of a free-standing, dwarfing, and precocious apple rootstock. Subsequent research has indicated that union breakage on Mark occurred with some cultivars; therefore, support was recommended (Perry, 1990). Although Mark is precocious and productive with several apple cultivars (Ferree, 1989; NC-140, 1991; Perry, 1990), it has not been widely tested in orchard system trials.

Palmette leader training has been used as a restructuring technique to improve light penetration into the canopies of mature apple trees on seedling and semistandard rootstocks, and it has increased yields and improved fruit color and size (Elfving et al., 1990; Ferree et al., 1990; Lakso et al., 1989). Because this training system proved promising in restructuring older trees by improving light distribution and fruit quality, the palmette leader was evaluated as a training system. The palmette leader system on either a dwarfing or semidwarfing rootstock was compared to the standard central leader and slender spindle systems that Ferree et al. (1989) found to be efficient.

\footnotetext{
Received for publication 29 Nov. 1993. Accepted for publication 7 Mar. 1994. Salaries and research support provided by state and federal funds appropriated to the Ohio Agricultural Research and Development Center, The Ohio State Univ., Wooster. Journal article no. 217-93. The cost of publishing this paper was defrayed in part by the payment of page charges. Under postal regulations, this paper therefore must be hereby marked advertisement solely to indicate this fact.

${ }^{1}$ Professor.
}

\section{Materials and Methods}

'Lawspur Rome Beauty' ('Lawspur') and 'Smoothee Golden Delicious' ('Smoothee') trees were planted in 1987 in slender spindle, central leader, and palmette leader training systems. Trees were planted in north-south rows on a fine, loamy mixed mesic typic fragiudalf soil in Wooster, Ohio. Trees trained to the slender spindle were on Mark rootstock and were spaced at $2 \times 4 \mathrm{~m}$ (1250 trees/ha). Trees trained as central leaders or palmette leaders were either on M.7 rootstock at a $5 \times 7$ $\mathrm{m}$ spacing (286 trees/ha) or Mark rootstock at a $3 \times 4$-m spacing (833 trees/ha). Approximately $25-\mathrm{m}$ rows of each system-scionrootstock combination were randomized within each of five replicate blocks with $9 \mathrm{~m}$ between blocks. Guard rows were planted on both edges of the plantings and between each rootstock-training system. Generally, the trees were nonfeathered when planted.

Slender spindle trees were supported by wooden posts ( $2 \mathrm{~m}$ protruding above the soil), and beginning in 1988, the leaders were treated by annual leader replacement. The original intention was that the palmette leader and central leader trees would be free-standing. However, because some 'Rome Beauty'-Mark graft unions broke in another planting, trees on Mark were supported by metal fence posts beginning in 1989. Palmette leader trees were allowed to develop a bottom tier of scaffold branches in 1987 and 1988; in subsequent years, strong growth was permitted to develop only in the north-south direction of the row. For each training system, the trees were evenly divided, and upright vigorous limbs or limbs that needed to be removed on half of the trees were pruned. On the other half these limbs were bent down either by tying or applying weights to control growth beginning in Spring 1989 and annually thereafter. Upright limbs that were desired as scaffolds were positioned at a $60^{\circ}$ angle to the central leader; unneeded limbs were positioned at or slightly below horizontal.

Scaffold limbs on 15 replicate trees of each scion-rootstock combination that either were or were not bent in 1989 were selected to examine effects on flower and fruit production. Shoot growth and number of flowers and fruit were measured on these same limbs in 1989 and 1990.

Length of 10 terminal shoots on each tree was measured in 1990 and 1991. Yield per tree and trunk circumference were measured on all trees annually to calculate trunk crosssectional area (TCA). The time required for pruning and training was recorded in 1989 to 1991. Following the 1992 growing season, tree height and spread were measured. In 1992, 'Smoothee' fruit count per tree was determined using a weight sizer ( FMC, San Jose, Calif.), and fruit were separated into the following size classes (diameter in millimeters): $\geq 80$ (box size 80 to 88 ), 79 to 73 (100 to $113), 72$ to 57 (125 to 138). Fruit were graded according to commercial standards.

\section{Results}

In 1990, 'Lawspur' shoots were slightly longer than those on 'Smoothee', but the reverse was true in 1991 (Table 1). Following 6 years of growth, 'Smoothee' trees averaged 20\% larger TCA than 'Lawspur' trees, and 'Smoothee' also had taller and more spreading trees. In 1989 at 3 years, $70 \%$ and $26 \%$ of 'Smoothee' and 'Lawspur' trees, respectively, produced some fruit. In subsequent years, 'Smoothee' had consistently higher yields than 'Lawspur'. Even though trees were larger, 'Smoothee' had a higher cumulative efficiency than 'Lawspur'.

Training system had no influence on tree size when only trees on Mark were compared (data not shown). In the first production year (1989), only $30 \%$ of the trees in the slender spindle system had fruit, but $50 \%$ of the trees in the central leader and palmette leader produced some fruit. Cumulative yield efficiency, when measured by yield per unit TCA, was lower on the slender spindle than palmette leader-trained trees (Table 1). However, the slender spindle had the highest cumulative yield per unit of land.

Yield for 3-year-old trees (1989) was similar for all training systems (Table 1). By 1991, 'Smoothee' trees trained as slender spindles had significantly higher yields per hectare than any other cultivar training system combinations (Fig. 1). Similar results were noted in 1992 for yield per hectare and cumulative yield. Trees trained as palmette leaders in the fifth and sixth year tended to have higher yields than those trained as central leaders. Training system had no influence on 'Lawspur' yields, and 'Lawspur' yields did not increase in 1992 as they did with 'Smoothee', likely because a severe fireblight infection occurred during bloom on 'Lawspur' in 1992. The fireblight infection was not influenced by rootstock, training system, or bending and resulted in the following percentages of 'Lawspur' 
Table 1. Early growth and production of 'Smoothee Golden Delicious' (Smoothee) and 'Lawspur Rome Beauty' (Lawspur) as influenced by three training systems and the use of bending.

\begin{tabular}{|c|c|c|c|c|c|c|c|c|c|c|c|c|c|}
\hline \multirow[b]{3}{*}{ Variable } & \multicolumn{6}{|c|}{ Tree size } & & & & & & & \\
\hline & \multicolumn{2}{|c|}{$\begin{array}{l}\text { Avg shoot } \\
\text { length }(\mathrm{cm})\end{array}$} & \multirow{2}{*}{$\begin{array}{l}1992 \\
\mathrm{TCA}^{\mathrm{z}} \\
\left(\mathrm{cm}^{2}\right)\end{array}$} & \multirow{2}{*}{$\begin{array}{l}\mathrm{Ht} \\
(\mathrm{m})\end{array}$} & \multirow{2}{*}{$\begin{array}{l}\text { Spread } \\
\text { (m) }\end{array}$} & \multirow{2}{*}{$\begin{array}{l}\text { Vol } \\
\left(\mathrm{m}^{3}\right)\end{array}$} & \multicolumn{5}{|c|}{ Yield/tree $(\mathrm{kg})$} & \multicolumn{2}{|c|}{$\begin{array}{l}\text { Cumulative } \\
\text { efficiency }\end{array}$} \\
\hline & 1990 & $\overline{1991}$ & & & & & 1989 & 1990 & 1991 & 1992 & $\overline{\text { Cumulative }}$ & $\mathrm{kg} \cdot \mathrm{cm}^{-2}$ & t.hat ${ }^{-1}$ \\
\hline Smoothee & $24.5 \mathrm{~b}^{\mathrm{y}}$ & $25.9 \mathrm{a}$ & $38.0 \mathrm{a}$ & $2.96 \mathrm{a}$ & $3.0 \mathrm{a}$ & $7.2 \mathrm{a}$ & $5.5 \mathrm{a}$ & $9.4 \mathrm{a}$ & $15.9 \mathrm{a}$ & $40.8 \mathrm{a}$ & $62.7 \mathrm{a}$ & $1.68 \mathrm{a}$ & $43.2 \mathrm{a}$ \\
\hline Lawspur & $26.6 \mathrm{a}$ & $24.5 \mathrm{~b}$ & $30.3 \mathrm{~b}$ & $2.77 \mathrm{~b}$ & $2.7 \mathrm{~b}$ & $4.9 \mathrm{~b}$ & $2.0 \mathrm{~b}$ & $8.1 \mathrm{~b}$ & $10.7 \mathrm{~b}$ & $12.2 \mathrm{~b}$ & $25.4 \mathrm{~b}$ & $0.80 \mathrm{~b}$ & $14.5 \mathrm{~b}$ \\
\hline \multicolumn{14}{|l|}{ Training system } \\
\hline Palmette leader & $25.3 \mathrm{ab}$ & 24.5 & $36.9 \mathrm{a}$ & 2.87 & $3.0 \mathrm{a}$ & $6.7 \mathrm{a}$ & 4.3 & $9.4 \mathrm{a}$ & $14.2 \mathrm{a}$ & $30.6 \mathrm{a}$ & $49.3 \mathrm{a}$ & $1.30 \mathrm{a}$ & $25.4 \mathrm{~b}$ \\
\hline Central leader & $27.7 \mathrm{a}$ & 25.9 & $35.7 \mathrm{a}$ & 2.85 & $2.9 \mathrm{a}$ & $6.6 \mathrm{a}$ & 3.8 & $7.8 \mathrm{~b}$ & $13.8 \mathrm{a}$ & $28.5 \mathrm{a}$ & $46.9 \mathrm{a}$ & $1.27 \mathrm{ab}$ & $23.9 \mathrm{~b}$ \\
\hline Slender spindle & $22.8 \mathrm{~b}$ & 24.9 & $28.0 \mathrm{~b}$ & 2.81 & $2.4 \mathrm{~b}$ & $4.5 \mathrm{~b}$ & 2.9 & $9.0 \mathrm{a}$ & $11.3 \mathrm{~b}$ & $18.4 \mathrm{~b}$ & $33.2 \mathrm{~b}$ & $1.14 \mathrm{~b}$ & $41.5 \mathrm{a}$ \\
\hline \multicolumn{14}{|l|}{ Treatment } \\
\hline Control & $26.8 \mathrm{a}$ & 25.5 & 34.7 & 2.86 & 2.9 & 6.3 & 3.3 & 8.8 & 13.1 & 26.8 & 43.7 & 1.19 & 28.2 \\
\hline Bending & $24.4 \mathrm{~b}$ & 24.8 & 33.7 & 2.87 & 2.8 & 5.9 & 4.2 & 8.7 & 13.5 & 26.5 & 44.7 & 1.30 & 29.7 \\
\hline \multicolumn{14}{|l|}{ F significance } \\
\hline Cultivar (C) & $* *$ & $* *$ & $* *$ & $* *$ & $* *$ & ** & $* *$ & $* *$ & ** & $* *$ & $* *$ & $* *$ & $* *$ \\
\hline System (S) & $* *$ & * & ** & NS & ** & $* *$ & NS & ** & $* *$ & $* *$ & ** & $* *$ & $* *$ \\
\hline $\mathrm{C} \times \mathrm{S}$ & NS & NS & NS & NS & $* *$ & $* *$ & NS & NS & $* *$ & NS & NS & $* *$ & $* *$ \\
\hline Bending (B) & $* *$ & NS & NS & NS & NS & NS & NS & NS & NS & NS & NS & NS & NS \\
\hline $\mathrm{C} \times \mathrm{B}$ & * & NS & NS & NS & NS & * & NS & NS & NS & NS & NS & NS & NS \\
\hline $\mathrm{S} \times \mathrm{B}$ & * & NS & NS & NS & NS & NS & NS & NS & NS & NS & NS & NS & NS \\
\hline $\mathrm{C} \times \mathrm{S} \times \mathrm{B}$ & NS & NS & NS & NS & NS & NS & NS & NS & * & NS & NS & NS & NS \\
\hline
\end{tabular}

zTCA $=$ trunk cross-sectional area.

${ }^{\mathrm{y}}$ Mean separation with main effect column by Duncan's multiple range test at $P \leq 0.05$. Data are means of the following number of observations: cultivar, 132 ; training system, 99; treatment, 64.

ss, *** Nonsignificant or significant at $P \leq 0.05$ or 0.01 , respectively.

trees with no yield or $<5 \mathrm{~kg}$ of fruit per tree: palmette leader, $36 \%$; central leader, $30 \%$; and slender spindle, $54 \%$.

Bending treatments, begun in 1989 , reduced shoot growth slightly in 1990 but had no significant effect on tree size, yield, or cumulative yield efficiency (Table 1). A detailed examination of branches that were bent demonstrated that bending increased limb crosssectional area (CSA) in 1989 and flowers per unit of branch CSA in 1989 and 1990 (Table 2). Fruit count per unit limb CSA was higher with trees on M.7 than on Mark rootstock in 1989 and 1990. In the initial year of bending (1989), limbs of trees on M.7 had more flowers per unit limb area than those on Mark. However, the reverse was true on the same limbs without additional bending in 1990. The significant cultivar $\times$ rootstock interaction was due to the $44 \%$ higher number of fruit per unit limb area of 'Smoothee' on M.7 compared to 'Smoothee' on Mark, with essentially no difference between rootstocks with 'Lawspur'.

There was no significant interaction between any limb bending and other factors in this study. The additional time required to accomplish the bending of unwanted limbs and to encourage fruiting of structural limbs required 5.9 and $4.8 \mathrm{~h} \cdot \mathrm{ha}^{-1}$ for the central leader and palmette leaders, respectively, on M.7. Nearly double this time was required for these systems on Mark due to the increased number of trees per hectare. Pruning out unwanted limbs as opposed to bending them required fewer hours (18 h.ha ${ }^{-1}$ less $)$ in the slender spindle system.

To eliminate the confounding effect of rootstock and training system that existed when all three training systems were compared, a second analysis of the data was performed omitting the slender spindle trees. Trees on Mark began bearing fruit earlier than trees on M.7. In 1991 and 1992, trees on M.7 had higher yields and a higher cumulative yield per tree (Table 3) than smaller trees on Mark. Trees on these two rootstocks had similar cumulative yield efficiency (yield $\div$ TCA), but due to the higher number of trees per hectare, trees on Mark had consistently higher yields per hectare than trees on M.7. In 1990, trees on M.7 trained as central leaders had low yields, which resulted in a significant rootstock $\times$ system interaction that did not occur in subsequent years. The only interaction involving bending limbs showed that bending limbs of trees on Mark resulted in an $11 \%$ (3.8 t) increase in cumulative tons of fruit per hectare, but bending did not influence yields of trees on M.7.

Significant interactions occurred among rootstock, cultivar, and training system (Fig. $2 \mathrm{a}-\mathrm{c})$. Cumulative yield per tree for 'Smoothee' in the palmette leader system did not differ between rootstocks, but in the central leader system, trees on M.7 had higher yields than

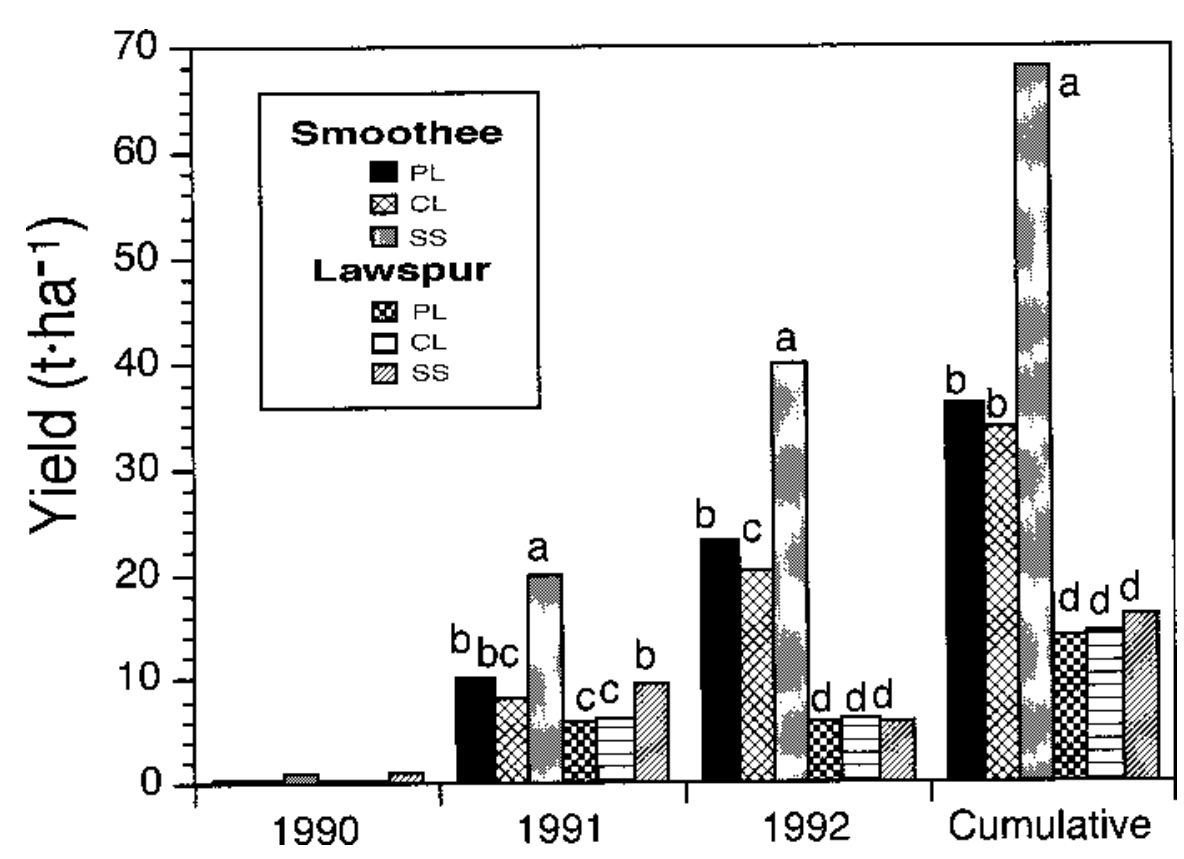

Fig. 1. The influence of palmette leader (PL), central leader (CL), or slender spindle (SS) training systems on yield of 'Smoothee Golden Delicious' (Smoothee) or 'Lawspur Rome Beauty' (Lawspur) over time. Data are means of 50 observations for PL and CL and 34 observations for SS. 
trees on Mark (Fig. 2a). 'Lawspur' cumulative yields per tree did not differ between rootstocks in the central leader system, but in the palmette leader, yields on M.7 were higher than on Mark. Cumulative yield efficiency was greater for 'Smoothee' than for 'Lawspur' in the cen- tral leader system, and rootstocks had no effect in this system (Fig. 2b). In the palmette leader system, 'Smoothee' trees on Mark were much more efficient than 'Lawspur' trees on Mark. There was no difference for a given cultivar in yield efficiency among training

Table 2. Influence of limb bending on growth, flowering, and fruiting on limbs of 'Smoothee Golden Delicious' (Smoothee) and 'Lawspur Rome Beauty' (Lawspur) on either M.7 or Mark rootstocks.

\begin{tabular}{|c|c|c|c|c|c|c|c|}
\hline \multirow[b]{2}{*}{ Variable } & \multicolumn{3}{|c|}{1989} & \multicolumn{4}{|c|}{1990} \\
\hline & $\begin{array}{l}\mathrm{Limb} \\
\mathrm{CSA} \\
\left(\mathrm{cm}^{2}\right) \\
\end{array}$ & $\begin{array}{c}\text { Flowers/ } \\
\text { CSA }\end{array}$ & $\begin{array}{l}\text { Fruit/ } \\
\text { CSA }\end{array}$ & $\begin{array}{l}\text { Limb } \\
\text { CSA } \\
\left(\mathrm{cm}^{2}\right) \\
\end{array}$ & $\begin{array}{c}\Delta \mathrm{CSA} \\
1990-89 \\
\left(\mathrm{~cm}^{2}\right)\end{array}$ & $\begin{array}{c}\text { Flowers/ } \\
\text { CSA }\end{array}$ & $\begin{array}{c}\text { Fruit/ } \\
\text { CSA }\end{array}$ \\
\hline \multicolumn{8}{|l|}{ Cultivar } \\
\hline Smoothee & $2.09 b^{z}$ & $18.0 \mathrm{a}$ & 8.7 & 3.4 & 1.35 & 5.0 & 5.6 \\
\hline Lawspur & $2.53 \mathrm{a}$ & $10.6 \mathrm{~b}$ & 8.0 & 3.8 & 1.29 & 10.2 & 5.7 \\
\hline \multicolumn{8}{|l|}{ Rootstock } \\
\hline Mark & $2.67 \mathrm{a}$ & $11.9 \mathrm{~b}$ & $7.1 \mathrm{~b}$ & $4.4 \mathrm{a}$ & $1.73 \mathrm{a}$ & $8.1 \mathrm{a}$ & $4.8 \mathrm{~b}$ \\
\hline M.7 & $1.95 \mathrm{~b}$ & $16.5 \mathrm{a}$ & $9.7 \mathrm{a}$ & $2.8 \mathrm{~b}$ & $0.91 \mathrm{~b}$ & $7.2 \mathrm{~b}$ & $6.4 \mathrm{a}$ \\
\hline \multicolumn{8}{|l|}{ Treatment } \\
\hline Control & $2.14 b$ & $13.2 \mathrm{~b}$ & 8.3 & 3.5 & 1.38 & $7.3 \mathrm{~b}$ & 5.7 \\
\hline Bending & $2.48 \mathrm{a}$ & $15.3 \mathrm{a}$ & 8.5 & 3.7 & 1.26 & $8.0 \mathrm{a}$ & 5.5 \\
\hline \multicolumn{8}{|l|}{ F Significance ${ }^{z}$} \\
\hline Cultivar (C) & $* *$ & $* *$ & NS & NS & NS & NS & NS \\
\hline Rootstock (R) & $* *$ & $* *$ & $* *$ & $* *$ & $* *$ & $* *$ & $* *$ \\
\hline $\mathrm{C} \times \mathrm{R}$ & NS & NS & $* *$ & NS & NS & NS & NS \\
\hline Bending (B) & $* *$ & $*$ & NS & NS & NS & $* *$ & NS \\
\hline $\mathrm{C} \times \mathrm{B}$ & NS & NS & NS & NS & NS & NS & NS \\
\hline $\mathrm{R} \times \mathrm{B}$ & NS & NS & NS & NS & NS & NS & NS \\
\hline $\mathrm{C} \times \mathrm{R} \times \mathrm{B}$ & NS & NS & NS & NS & NS & NS & NS \\
\hline
\end{tabular}

${ }^{\mathrm{z}} \mathrm{CSA}=$ cross sectional area.

${ }^{\mathrm{y}} \triangle \mathrm{CSA}=$ change in CSA.

'Mean separation within main effect columns by Duncan's multiple range test, $P \leq 0.05$. Each mean is the average of 60 observations.

ns,*,** Nonsignificant and significant at $P \leq 0.05$ or 0.01 , respectively.

Table 3. Yield and production efficiency of 'Smoothee Golden Delicious' (Smoothee) and 'Lawspur Rome Beauty' (Lawspur) as influenced by rootstock, training system and bending.

\begin{tabular}{|c|c|c|c|c|c|c|}
\hline \multirow[b]{2}{*}{ Variable } & \multicolumn{2}{|c|}{ Cumulative yield } & \multicolumn{4}{|c|}{ Yield $\left(\mathrm{t} \cdot \mathrm{ha}^{-1}\right)$} \\
\hline & $\mathrm{kg} \cdot \mathrm{cm}^{-2}$ & $\mathrm{~kg} /$ tree & 1990 & 1991 & 1992 & $\overline{\text { Cumulative }}$ \\
\hline \multicolumn{7}{|l|}{ Rootstock } \\
\hline Mark & $2.87^{z}$ & 89 & $0.30 \mathrm{a}$ & $11.2 \mathrm{a}$ & $18.0 \mathrm{a}$ & $33.6 \mathrm{a}$ \\
\hline M.7 & 2.86 & 122 & $0.09 \mathrm{~b}$ & $4.0 \mathrm{~b}$ & $10.7 \mathrm{~b}$ & $15.8 \mathrm{~b}$ \\
\hline \multicolumn{7}{|l|}{ System } \\
\hline Palmette leader & 2.86 & 108 & $0.22 \mathrm{a}$ & 7.8 & 14.6 & 25.3 \\
\hline Central leader & 2.80 & 103 & $0.17 \mathrm{~b}$ & 7.4 & 14.1 & 24.1 \\
\hline \multicolumn{7}{|l|}{ Cultivar } \\
\hline Smoothee & $3.68 \mathrm{a}$ & $146 \mathrm{a}$ & 0.20 & $9.3 \mathrm{a}$ & $22.0 \mathrm{a}$ & $35.3 \mathrm{a}$ \\
\hline Lawspur & $1.99 \mathrm{~b}$ & $65 \mathrm{~b}$ & 0.19 & $5.9 \mathrm{~b}$ & $6.7 \mathrm{~b}$ & $14.1 \mathrm{~b}$ \\
\hline \multicolumn{7}{|l|}{ Treatment } \\
\hline Control & 2.74 & 104 & 0.18 & 7.4 & 14.1 & 23.9 \\
\hline Bending & 2.92 & 107 & 0.21 & 7.8 & 14.5 & 25.5 \\
\hline \multicolumn{7}{|l|}{ F Significance } \\
\hline Rootstock (R) & NS & NS & $* *$ & $* *$ & $* *$ & $* *$ \\
\hline System (S) & NS & NS & $* *$ & NS & NS & NS \\
\hline $\mathrm{S} \times \mathrm{R}$ & NS & NS & $*$ & NS & NS & NS \\
\hline Cultivar (C) & $* *$ & $* *$ & NS & $* *$ & $* *$ & $* *$ \\
\hline $\mathrm{C} \times \mathrm{R}$ & $* *$ & NS & NS & $* *$ & $* *$ & $* *$ \\
\hline $\mathrm{S} \times \mathrm{C}$ & NS & NS & ns & NS & NS & NS \\
\hline $\mathrm{S} \times \mathrm{C} \times \mathrm{R}$ & $* *$ & $* *$ & NS & $*$ & $* *$ & $* *$ \\
\hline Bending (B) & NS & NS & NS & NS & NS & NS \\
\hline $\mathrm{R} \times \mathrm{B}$ & NS & NS & NS & NS & NS & $*$ \\
\hline $\mathrm{S} \times \mathrm{B}$ & NS & NS & NS & NS & NS & NS \\
\hline $\mathrm{S} \times \mathrm{R} \times \mathrm{B}$ & NS & NS & NS & NS & NS & NS \\
\hline $\mathrm{C} \times \mathrm{B}$ & NS & NS & NS & NS & NS & NS \\
\hline $\mathrm{C} \times \mathrm{R} \times \mathrm{B}$ & NS & NS & NS & NS & NS & NS \\
\hline $\mathrm{S} \times \mathrm{C} \times \mathrm{B}$ & NS & NS & NS & NS & NS & NS \\
\hline $\mathrm{S} \times \mathrm{C} \times \mathrm{R} \times \mathrm{B}$ & NS & NS & NS & NS & NS & NS \\
\hline
\end{tabular}

${ }^{2}$ Mean separation within main effect columns by Duncan's multiple range test at $P \leq 0.05$. Each mean is the average of 40 observations.

Ns, **** Nonsignificant and significant at $P \leq 0.05$ or 0.01 , respectively.

systems. The cumulative yields per hectare were highest for 'Smoothee' on Mark in both training systems (Fig. 2c). However, cumulative yields for 'Smoothee' on M.7 and 'Lawspur' on Mark or M.7 were low irrespective of training system.

\section{Discussion}

Although 'Smoothee' was a productive and efficient cultivar in Ferree et al.'s (1989) study, Ferree and Rhodus's (1993) direct comparison spanning 10 years showed that 'Lawspur' produced $32 \%$ more fruit per hectare than 'Smoothee'. The superior performance of 'Smoothee' in this study was likely due to the severe fireblight infection of 'Lawspur' in 1992, and a less severe infection that occurred in 1991.

Yields per hectare of 'Smoothee Golden Delicious' on Mark trees trained as slender spindles were slightly higher in this study than in a previous trial of this cultivar on M.7 over the first 6 years (Ferree et al., 1989), even with $42 \%$ fewer trees per hectare. The high early yields may have been due to the precocity of Mark in this trial compared to M.9 in the previous trial. Trees on Mark have shown exceptional precocity with several cultivars (Ferree, 1989; NC-140, 1991; Perry, 1990).

Restructuring mature central leader (Elfving et al., 1990; Lakso et al., 1989) or open center trees (Ferree et al., 1990) as palmette leaders improved light penetration into the canopies and fruit color and quality. These results show that trees can be established using this training system without loss of yield, compared to central-leader-trained trees.

Bending to control growth and induce early cropping has been recommended as a useful practice in intensive orchards (Hamzakheyl et al., 1976; Oberhofer, 1990; Peterson, 1989; Tromp, 1970). Ferree and Schmid (1993) demonstrated that bending unwanted shoots rather than removing them resulted in increased flowering of young 'Fuji' apple trees. A detailed comparison of bending or not bending scaffold limbs in this study showed an increase in flower density for 2 years when limbs were bent. When cumulative yields per hectare were evaluated, bending of trees on Mark resulted in an $11 \%$ (3.8 t) increase of fruit with no influence on trees on M.7. The increased time required for bending ranged from 5 to $6 \mathrm{~h}$ for trees on M.7, from 10 to $12 \mathrm{~h}$ for trees on Mark, and $18 \mathrm{~h}$ for the slender spindle. If labor for bending costs $\$ 6 / \mathrm{h}$, the yield increase of trees on Mark would cost $\$ 60$ to $\$ 72$ per hectare, which would be recovered by selling an additional 3.8 tons of fruit.

\section{Literature Cited}

Barritt, B.H. 1989. Deciding on a high density orchard system, p. 89-96. In: A.B. Peterson (ed.). Intensive orcharding. Good Fruit Grower, Yakima, Wash.

Carlson, R.F. 1981. The MARK apple rootstock. Fruit Varieties J. 35(2):78-79.

Elfving, D.C., I. Schechter, R.A. Cline, and W.F. Pierce. 1990. Palmette leader and central leader 


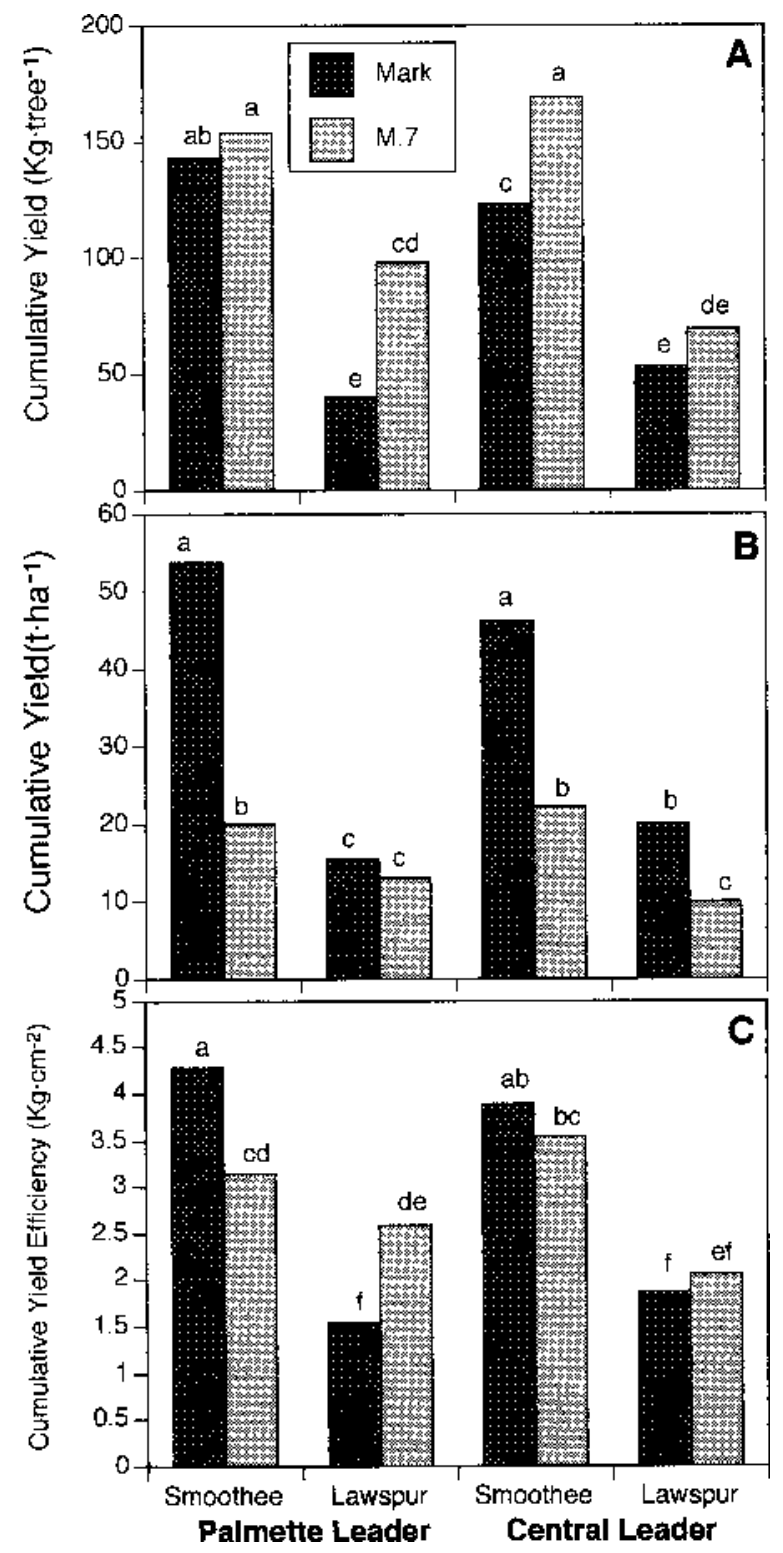

Fig. 2. The influence of training system and rootstock on (a) cumulative yield per tree, (b) cumulative yield efficiency, and (c) cumulative yield per hectare of 'Smoothee Golden Delicious' (Smoothee) and 'Lawspur Rome Beauty' (Lawspur). Data are means of 10 observations. tree forms compared for light distribution, productivity, and fruit quality of 'McIntosh' apple trees. HortScience 25:1386-1388.

Ferree, D.C. 1989. Early performance of MAC apple rootstocks in Ohio. Fruit Varieties J. 43(2):102-105.

Ferree, D.C., R.C. Funt, and B.L. Bishop. 1989 Yield and production efficiency of four apple cultivars in selected orchard management systems. J. Amer. Soc. Hort. Sci. 114:863-868.

Ferree, D.C. and W.T. Rhodus. 1993. Influence of mechanical hedging or root pruning on apple trees in intensive orchards. J. Amer. Soc. Hort. Sci. 118:707-713.

Ferree, D.C. and J.C. Schmid. 1994. Influence of training stakes and various pruning and bending techniques on early performance of 'Fuji' apple trees. Fruit Crops 1993: A summary of research, Ohio Agr. Res. and Dev. Ctr. Res. Circ. (In press.)

Ferree, D.C., J.C. Schmid, J.R. Schupp, and I.J. Warrington. 1990. Influence of pruning treatments on mature spur-bound 'Starkrimson Delicious' apple trees. Fruit crops 1990: A summary of research, Ohio Agr. Res. and Dev. Ctr. Res. Circ. 297:16-22.

Hamzakheyl, N., D.C. Ferree, and F.O. Hartman. 1976. Effect of lateral shoot orientation on growth and flowering of young apple trees. HortScience 11:393-395.

Lakso, A.N., T.L. Robinson, and S.G. Carpenter 1989. The palmette leader: A tree design for improved light distribution. HortScience 24:271275 .

NC-140. 1991. Performance of 'Starkspur Supreme Delicious' apple on 9 rootstocks over 10 years in the NC-140 cooperative planting. Fruit Varieties J. 45(4): 192-199.

Oberhofer, H. 1990. Pruning the slender spindle. British Columbia Ministry Agr. and Fisheries, Summerland, Canada.

Perry, R.L. 1990. MARK in the apple rootstock arsenal. Compact Fruit Tree 23:1-7.

Peterson, A.B. 1989. Intensive orcharding. Good Fruit Grower, Yakima, Wash.

Robinson, T.L., A.N. Lakso, and S.G. Carpenter. 1991. Canopy development, yield and fruit quality of 'Empire' and 'Delicious' apple trees grown in four orchard production systems for ten years. J. Amer. Soc. Hort. Sci. 116:179-187.

Tromp, J. 1970. Shoot orientation effects on growth and flower bud formation in apple. Acta. Bot. Necrl. 19:535-538. 